\title{
The Wellbeing of Patients -Commentary on "Music does not Alter Anxiety in Patients with Suspected Lung Cancer Undergoing Bronchoscopy: A Randomised Controlled Trial" - European Clinical Respiratory Journal
}

\author{
Elisabeth Jeppesen ${ }^{1 *}$, Carsten M Pedersen ${ }^{2}$, Vibeke Backer ${ }^{1}$ \\ ${ }^{1}$ Department of Respiratory Medicine, Bispebjerg Hospital, Denmark \\ ${ }^{2}$ Department of Thoracic Anaesthesiology, Rigshospitalet, Denmark
}

Submission: January 20, 2017; Published: May 08, 2017

*Corresponding author: Elisabeth Jeppesen, RN, Department of Respiratory Medicine, Bispebjerg Hospital, Copenhagen, Denmark Email: Elisabeth.Margrethe.Langvall.Jeppesen@regionh.dk

\section{Commentary}

Besides ensuring a high diagnostic yield and safety through bronchoscopy it is the opinion of the authors that it is important to ensure the wellbeing of patients. That was our focus in the study published in European Clinical Respiratory Journal with the title "Music does not alter anxiety in patients with suspected lung cancer undergoing bronchoscopy: a randomised controlled trial”.

Patients undergoing different procedures in hospital settings may fear the anesthesia, surgical intervention and outcomes. Anxiety can determine increased intraoperative anesthetic requirement and also lead to a lower level of satisfaction with the treatment [1]. There has been a growing interest in the possible influences of anxiety on the course and outcomes of treatments, as well as in the study of anxiety-reducing interventions.

The thought of bronchoscopy, which is a common procedure in diagnosing lung cancer, may also trigger anxiety. Patients exhibit, for example, fear of breathlessness, pain, loss of control, and fear of the unknown [2].

Anxiety can be relieved with sedation [3-5]. At the outpatient clinic at Bispebjerg Hospital patients undergoing bronchoscopy are mainly sedated with Midazolam as a bolus injection. If an EBUS (Endobronchial Ultrasound) is expected, or the patient does not seem sufficiently sedated, this is obtained with Fentanyl, also as bolus injection. Figures 1-3 visualise the administration of Midazolam and Fentanyl to the patients included in the study. An increased higher dose of sedatives leads to an increased risk of respiratory depression [6-9]. A reduced lung function is common in patients undergoing bronchoscopy to detect lung cancer. Patients included in our study had a mean FEV1 of $75.0 \%$ (SD 22.3) of predicted, and in the excluded patients the mean FEV1 was even lower (66.4\% (SD 21.67)). Therefore sedatives must be given with caution, and it is of interest to investigate other means of relieving anxiety, fear and discomfort.

Music has been investigated earlier in relation to bronchoscopy, but with different outcomes, music genres, audio devices and dosage, and with contradictory findings [10-13]. Same findings apply to other invasive procedures $[14,15]$. We hypothesized, though, that "MusiCure-music as medicine" played before and during bronchoscopy might relieve anxiety for patients undergoing bronchoscopy to detect lung cancer. We chose "MusiCure-music as medicine" because it has been investigated before, and the composer has designed the music to be calming and soothing and promotes his music as medicine. Studies investigating MusiCure have mostly been done in connection with cardiac surgery and postoperatively. These studies have different outcomes, but most of them favour MusiCure [16-23].

Our primary outcome was Spielberger's State-Trait Anxiety Inventory (STAI). The STAI-State scores at the time of admission were similar in the two groups, in our study, whereas a significant 
difference in the STAI-State score (median (IQR) 35 (18) versus 43 (25); $p=0.03, r=-0.18$ ) was observed between the music and the control group prior to bronchoscopy, with lower scores in the music group, but a multiple regression analysis revealed that treatment group was not a significant predictor of STAIState level in the operating theatre when adjusting for gender and baseline anxiety.

This brought us to the conclusion that MusiCure played for 10 minutes before bronchoscopy does not alter anxiety and, in addition, that it is very important to look out for confounders when researching the effect of music on anxiety.

Administering music before and during bronchoscopy did not reduce the amount of sedatives neither (Table 1). Though we could not conclude that music could relieve the anxiety of patients who have to undergo bronchoscopy, or reduce amount of administered sedatives, we saw a highly significant
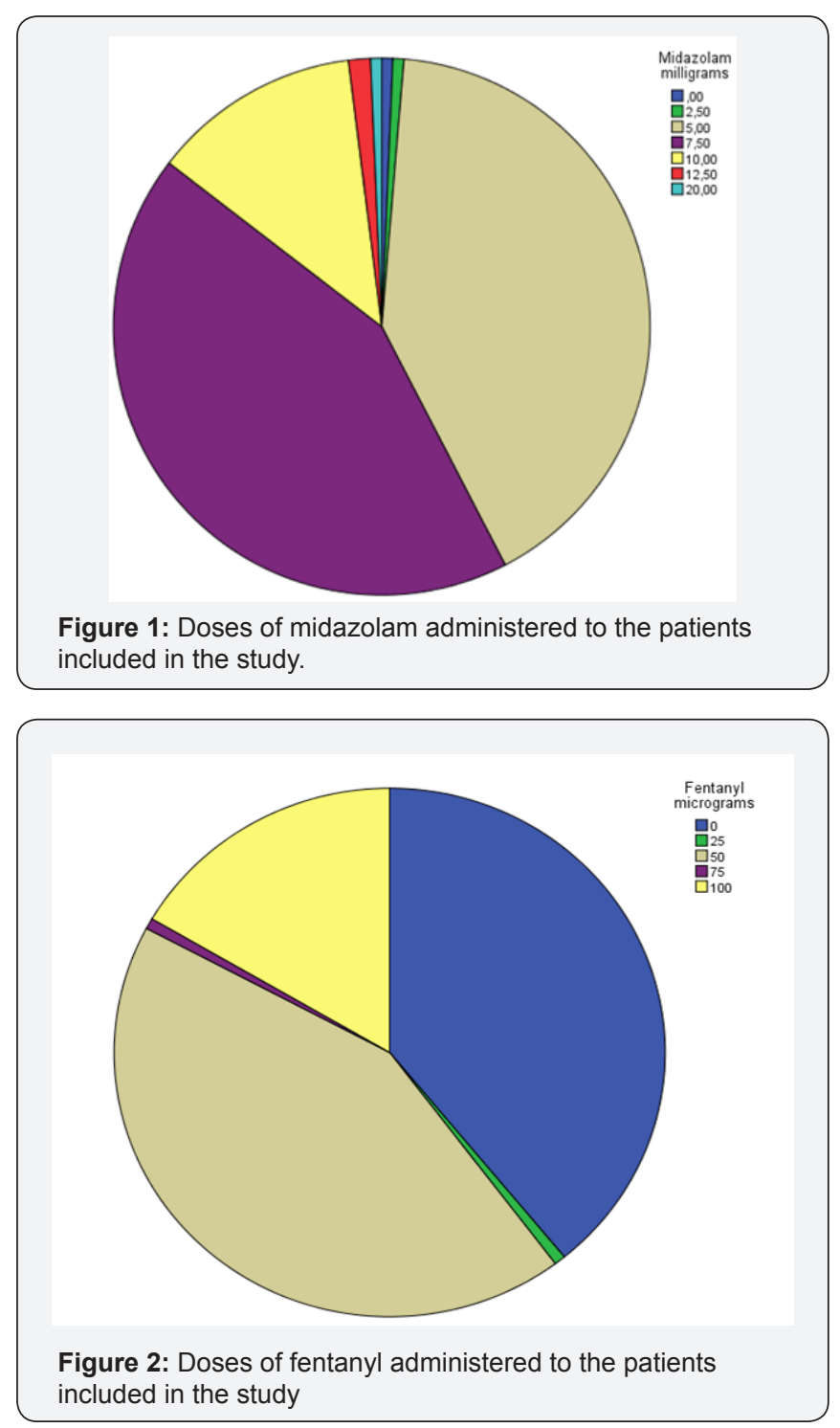

difference between the music and the no-music group rating their experience of sound in the operating theatre (Figure 4). So administering music to patients undergoing bronchoscopy might not relieve anxiety, but it enhances the comfort of patients undergoing bronchoscopy.

Table 1: Percent of patients receiving Midazolam and Fentanyl with music or no music. There are no significant differences between the groups on amount of sedatives.

\begin{tabular}{|c|c|c|c|c|c|c|c|}
\hline Midazolam & $0 \mathrm{mg}$ & $\begin{array}{l}2.5 \\
\mathrm{mg}\end{array}$ & $\begin{array}{l}5.0 \\
\mathrm{mg}\end{array}$ & $\begin{array}{l}7.5 \\
\mathrm{mg}\end{array}$ & $\begin{array}{c}10.0 \\
\mathrm{mg}\end{array}$ & $\begin{array}{c}12.5 \\
\mathrm{mg}\end{array}$ & $\begin{array}{c}20.0 \\
\mathrm{mg}\end{array}$ \\
\hline Music & $0.0 \%$ & $1.3 \%$ & $35.9 \%$ & $47.4 \%$ & $14.1 \%$ & $1.3 \%$ & $0.0 \%$ \\
\hline No-Music & $1.4 \%$ & $0.0 \%$ & $46.6 \%$ & $38.4 \%$ & $11.0 \%$ & $1.4 \%$ & $1.4 \%$ \\
\hline Fentanyl & 0 ug & $\begin{array}{l}25 \\
\text { ug }\end{array}$ & $50 \mathrm{ug}$ & $75 \mathrm{ug}$ & $\begin{array}{c}100 \\
\text { ug }\end{array}$ & & \\
\hline Music & $38.5 \%$ & $0.0 \%$ & $43.6 \%$ & $1.3 \%$ & $16.7 \%$ & & \\
\hline No-music & $39.7 \%$ & $1.4 \%$ & $42.5 \%$ & $0.0 \%$ & $16.4 \%$ & & \\
\hline
\end{tabular}
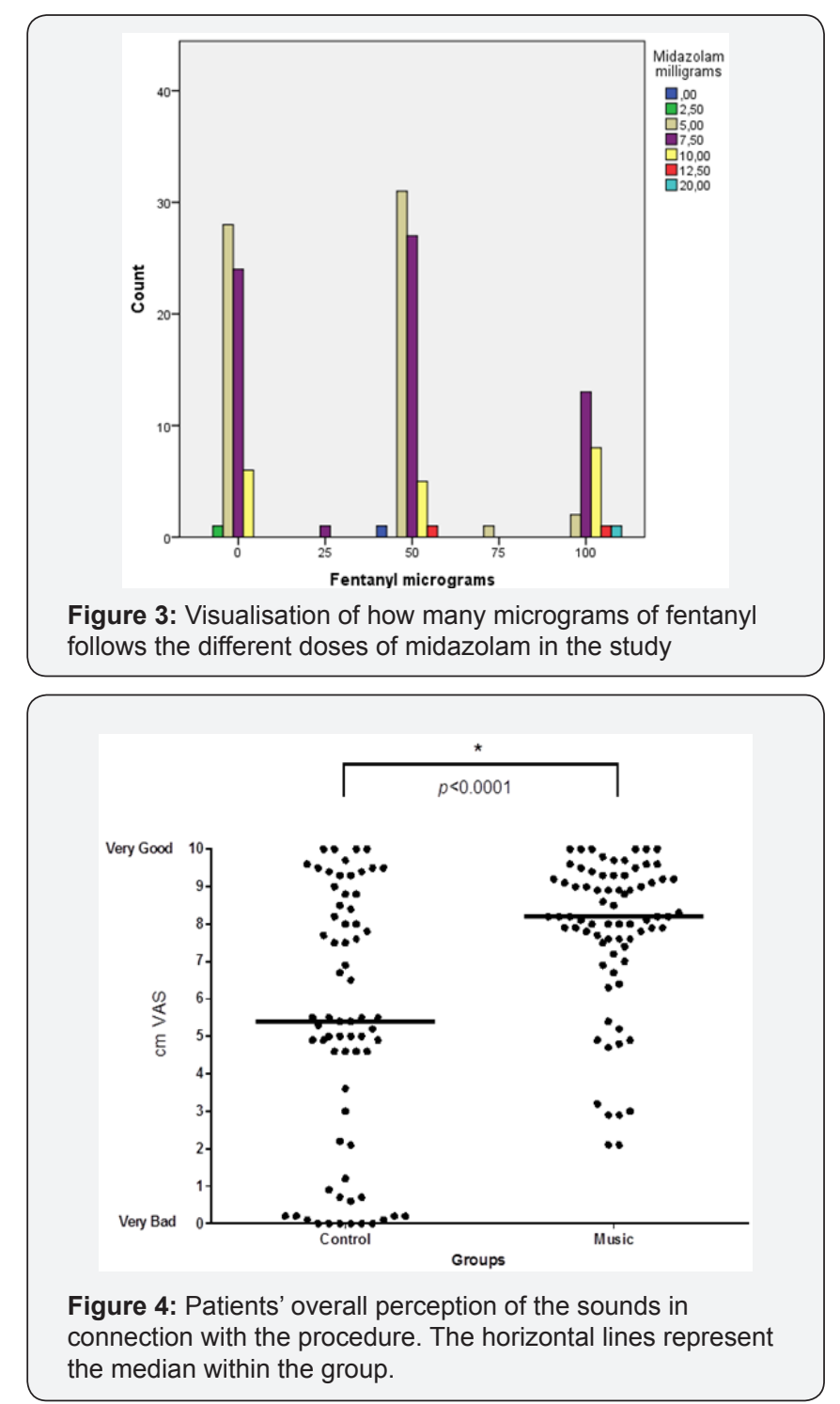


\section{References}

1) Caumo W, Schmidt AP, Schneider CN, Bergmann J, Iwamoto CW, et al. (2001) Risk factors for preoperative anxiety in adults. Acta Anaesthesiol Scand 45(3): 298-307.

2) Poi PJ, Chuah SY, Srinivas P, Liam CK (1998) Common fears of patients undergoing bronchoscopy. Eur Respir J 11(5): 1147-1149.

3) Putinati S, Ballerin L, Corbetta L, Trevisani L, Potena A (1999) Patient satisfaction with conscious sedation for bronchoscopy. CHEST 115(5): 1437-1440

4) Houghton CM, Raghuram A, Sullivan PJ, O’Driscoll R (2004) Premedication for bronchoscopy: a randomised double blind trial comparing alfentanil with midazolam. Respir Med 98(11): 1102-1107.

5) Matot I, Kramer M (2000) Sedation in outpatient bronchoscopy. Respir Med 94(12): 1145-1153.

6) Milman N, Faurschou P, Grode G, Jørgensen A (1998) Pulse oximetry during fibreoptic bronchoscopy in local anaesthesia: frequency of hypoxaemia and effect of oxygen supplementation.

7) Mouchantaf FG, Shostak E, Lamb CR (2012) Characteristics and financial costs of patients with respiratory failure at bronchoscopy. J Bronchology Interv Pulmonol 19(3): 188-194.

8) Jones AM, O’Driscoll R (2001) Do all patients require supplemental oxygen during flexible bronchoscopy? CHEST 119(6): 1906-1909.

9) Hong KS, Choi EY, Park DA, Park J (2015) Safety and Efficacy of the Moderate Sedation During Flexible Bronchoscopic Procedure: A Systematic Review and Meta-Analysis of Randomized Controlled Trials. Medicine (Baltimore) 94(40): e1459.

10) Dubois J, Bartter T, Pratter MR (1997) Music improves patient comfort level during outpatient bronchoscopy. Journal of Bronchology \& Interventional Pulmonology 4(1): 83.

11) Colt HG, Powers A, Shanks TG (1999) Effect of music on state anxiety scores in patients undergoing fiberoptic bronchoscopy. Chest 116(3): 819-824.

12) Triller N, Erzen D, Duh S, Petrinec Primozic M, Kosnik M (2006) Music during bronchoscopic examination: the physiological effects. A randomized trial. Respiration 73(1): 95-99.
13) Tam WW, Lo KK, Hui DS (2016) The effect of music during bronchoscopy: A meta-analysis. Heart Lung 45(2): 86-94.

14) Wang MC, Zhang LY, Zhang YL, Zhang YW, Xu XD, et al. (2014) Effect of Music in Endoscopy Procedures: Systematic Review and Meta-Analysis of Randomized Controlled Trials. Pain Med 15(10): 1786-1794.

15) Nilsson U (2008) The anxiety-and pain-reducing effects of music interventions: a systematic review. AORN J 87(4): 780-807.

16) Nilsson S, Kokinsky E, Nilsson U, Sidenvall B, Enskär K (2009) Schoolaged children's experiences of postoperative music medicine on pain, distress, and anxiety. Paediatr Anaesth 19(12): 1184-1190.

17) Nilsson U, Lindell L, Eriksson A, Kellerth T (2009) The effect of music intervention in relation to gender during coronary angiographic procedures: a randomized clinical trial. Eur J Cardiovasc Nurs 8(3): 200-206.

18) Nilsson $U$ (2009) The effect of music intervention in stress response to cardiac surgery in a randomized clinical trial. Heart Lung 38(3): 201207.

19) Nilsson U (2009) Soothing music can increase oxytocin levels during bed rest after open-heart surgery: a randomised control trial. J Clin Nurs 18(15): 2153-2161.

20) Thorgaard B, Henriksen BB, Pedersbaek G, Thomsen I (2004) Specially selected music in the cardiac laboratory - an important tool for improvement of the wellbeing of patients. Eur J Cardiovasc Nurs 3(1): 21-26.

21) Thorgaard P, Ertmann E, Hansen V, Noerregaard A, Spanggaard L (2005) Designed sound and music environment in postanaesthesia care units--a multicentre study of patients and staff. Intensive Crit Care Nurs 21(4): 220-225.

22) Weeks BP, Nilsson U (2011) Music interventions in patients during coronary angiographic procedures: a randomized controlled study of the effect on patients' anxiety and well-being. Eur J Cardiovasc Nurs 10(2): 88-93.

23) Fredriksson AC, Hellström L, Nilsson U (2009) Patients' perception of music versus ordinary sound in a postanaesthesia care unit: a randomised crossover trial. Intensive Crit Care Nurs 25(4): 208-213.

Your next submission with Juniper Publishers
will reach you the below assets
- Quality Editorial service
- Swift Peer Review
- Reprints availability
- E-prints Service
- Manuscript Podcast for convenient understanding
- Global attainment for your research
- Manuscript accessibility in different formats
( Pdf, E-pub, Full Text, Audio)
- Unceasing customer service
Track the below URL for one-step submission
https://juniperpublishers.com/online-submission.php

